\title{
ERROR CORRECTION MODEL ANALYSIS OF THE DETERMINANT OF STABILITY OF FINANCIAL SYSTEM IN INDONESIA
}

\author{
M. Rismawan Ridha ${ }^{1}$ \\ ${ }^{1}$ Badan Pusat Statistik Kabupaten Maluku Tengah \\ rismawan.ridha@bps.go.id ${ }^{1}$
}

\begin{abstract}
The current condition of economic openness is both an opportunity and a challenge that must be faced wisely by the government. Liberalization and economic integration will have an impact on financial market liberalization, which is highly vulnerable to create crisis in a banking system. This study aims to analyze the factors that influence the stability of the financial system in Indonesia by using the Error Correction Model (ECM). The variables used in this research is Capital Banking Credit sourced from Statistics Indonesia (BPS) and Exchange Rate, Inflation, and Money Supply sourced from the International Monetary Fund (IMF) between 2010 and 2015. The results of the study show that; 1) ECT coefficient which has negative and significant value explains that the model is valid. 2) Inflation significantly affects the stability of the financial system in Indonesia in the long and short term.
\end{abstract}

Keywords: ECM, Inflation, Stability of the financial system

\begin{abstract}
Abstrak
Kondisi keterbukaan ekonomi pada saat ini adalah sebuah peluang dan juga tantangan yang harus disikapi dengan bijak oleh pemerintah. Liberalisasi dan integrasi ekonomi akan berdampak pada liberalisasi pasar keuangan yang sangat rentan terhadap krisis perbankan. Penelitian ini bertujuan untuk menganalisis faktor yang memengaruhi stabilitas sistem keuangan di Indonesia dengan menggunakan analisis Error Correction Model (ECM). Variabel yang digunakan dalam penelitian ini yakni Posisi Kredit Modal Kerja yang bersumber dari Badan Pusat Statistik (BPS), data Nilai Tukar, Inflasi dan Uang Beredar bersumber dari International Monetary Fund (IMF) dengan periode 2010 - 2015. Hasil penelitian menunjukkan bahwa; 1) Koefisien ECT yang bernilai negatif dan signifikan menjelaskan bahwa model telah sah atau valid. 2) Inflasi memengaruhi secara signifikan stabilitas sistem keuangan di Indonesia dalam jangka panjang maupun jangka pendek.
\end{abstract}

Kata kunci: ECM, Inflasi, Stabilitas Sistem Keuangan 


\section{INTRODUCTION}

The current economic condition is a challenge that must be faced by the government and Bank Indonesia as the central bank in Indonesia (Negara et al., 2020). Besides internal challenges, Indonesia also faced with external challenges in the form of global competition between Indonesia and various countries in ASEAN which have entered the ASEAN Economic Community (AEC) since the end of 2015. The form of integration and liberalization of business markets in the ASEAN region will have an impact on financial market liberalization that often leads to financial fragility (Patcharee et. al, 2018). Thus, liberalization requires support in the form of prudent policies and effective supervision of a country's financial condition to minimize risk-taking from a crisis in the future economic period. The economic crisis that will arise due to market liberalization is mainly due to the financial market crisis. This crisis encourages every country to create a system of financial stability.

A stable financial system can allocate sources of funds and absorb shocks that occur in the economy. This system has done to prevent disruption of economic activity both in the real sector and the financial sector. Bank Indonesia, an institution that has monetary authority, demanded to be able to carry out its functions in achieving financial system stability and preparing Indonesia's economic and financial resilience in the era of globalization. If the financial system does not work well, the economy will become inefficient and the expected economic growth will not be achieved (Mariusz, 2016). With financial liberalization, the chances of a banking crisis will be higher (Mekki, 2018). Among the problems and challenges of financial stability in Indonesia at this time, it is necessary to have an empirical study that discusses the factors that influence and distinguish the long term and short term effects on the financial stability policies in Indonesia.

In statistics, several methods used to model the effect of independent variables on the dependent variable by examining the relationship in the long term and correcting short term disturbances in regression modeling. One of them namely the Error Correction Model (ECM). Mainly, ECM method is used to address the problem of non-stationary time-series data. Using non-stationary data in the time series model will produce unreliable and spurious results and will often lead to poor understanding and forecasting. This procedure used to break down the long term and short term connection between the variables factors with explanatory strategies to address the transient or short term disturbances (widely known as the speed of adjustment). This study aims to determine the factors that affect the stability of the financial system in Indonesia in the long term and short term as well as the effect of the balance correction process in the ECM regression equation model. There is still limited research about the stability of the financial system that provides evidence-based approximation on current capital banking credit. As an improvement, this study also employs another macroeconomic variable that tends to affect the stability of the financial system in Indonesia. 


\section{METHOD}

\section{Error Correction Model}

The analysis used is a descriptive quantitative approach using time series data utilizing the technique of the Error Correction Model. The notion of the Error Correction Model (ECM) is considered to be a very powerful organizing principle in applied econometrics and widely applied in various economics research. The ECM interpreted as a method of adjusting a policy instrument to maintain a target variable close to its desired value theoretically (Ruiz, 2019). Generally, many economic variables are non-stationary variables. To be able to handle the spurious regression issue, the combination of the variables must be stationary (Smith, 2000). Otherwise, any deviation from the equilibrium relationship would not be transitory. Consider the long term equation:

$$
Y_{t}=\beta_{0}+\beta_{1} X_{t}+u_{t}
$$

The Ordinary Least Square (OLS) residuals from (1) is a linear combination which is a measure of disequilibrium:

$$
\widehat{\boldsymbol{u}}_{t}=Y_{t}-\widehat{\boldsymbol{\beta}}_{0}-\widehat{\boldsymbol{\beta}}_{1} X_{t}
$$

Thus, a stationary test must be done to (2). If the linear combination is stationary at level $(\mathrm{I}=0)$ then it is said that the variables are cointegrated (Matthew, 2017). This relationship is a force that pulls the equilibrium error back to zero. The next step is estimating the ECM equation, which as follows:

$$
\Delta Y_{t}=\alpha_{0}+\alpha_{1} \Delta X_{t}+\alpha_{2} \widehat{u}_{t-1}+\varepsilon_{t}
$$

Let us conduct a test of significance parameter using F-test and T-test. A test of significance is a statistical test on a sampling distribution of such a statistic under the null hypothesis. The F-test is employed in multivariate analysis to check the hypothesis that each one model parameters are zero. It is also utilized in statistical analysis when comparing statistical models that are fitted using equivalent underlying factors and data set to work out the model with the best fit (Robert, 2017). That is:

$H_{0}: \beta_{1}=\beta_{2}=\cdots=\beta_{p}=0$

$H_{1}: \beta_{i} \neq 0 ; i=1,2, \ldots, p$

The F-test was first introduced by Ronald A. Fisher (hence F-test) and is known as a calculation of the ratio of variances. The F-statistic is defined as:

$$
F=\frac{S S R / p}{S S E /(n-p)}
$$

Where,

$$
\text { SSR }=\text { Sum Square of Regression }
$$




$$
\begin{aligned}
& \text { SSE }=\text { Sum Square of Error } \\
& n \quad=\text { number of observations } \\
& p \quad=\text { number of parameters }
\end{aligned}
$$

The T-test is used to prove the independent variables individually affect the dependent variable. To conduct this test, the following hypothesis is given:

$H_{0}: \beta_{i}=0$

$H_{1}: \beta_{i} \neq 0$

While the T-test is defined as:

$$
t=\frac{\beta_{i}}{\operatorname{se}\left(\beta_{i}\right)}
$$

Where,

$$
\begin{aligned}
& \beta_{i} \quad=\text { Coefficient of Regression } \\
& \operatorname{se}\left(\beta_{i}\right)=\text { Standard Error of Coefficient of Regression }
\end{aligned}
$$

Both of F-test and T-test will lead to rejecting $H_{0}$ if the statistics test value > statistics table value at $\alpha$ $=0.05$. The $\alpha_{2}$ coefficient from (3) known as the speed of adjustment must be negative and between -1 - 0 (Tursoy, 2017). Performing diagnostic testing of residuals is appropriate to meet the classical assumptions of Normality $\left(\varepsilon_{t} \sim N\left(0, \sigma^{2}\right)\right.$, No autocorrelation $\left(E\left(\varepsilon_{t}\right)=0\right)$, Homoscedasticity $\left(\operatorname{Var}\left(\varepsilon_{t}\right)=\sigma^{2}\right)$ and No Multicollinearity $\left(\operatorname{Cov}\left(\varepsilon_{i}, \varepsilon_{j}\right)=0\right)$.

\section{Research Variables}

The dependent variable used is the Capital Banking Credit as an approximation of the stability of the financial system. The independent variables used in this research are based on a previous study conducted by Auel (2011), which are Exchange Rate and Inflation. This study also attempts to improve by selecting a new macroeconomics variable, which is Money Supply. The definition of research variables is as follows:

1. Capital Banking Credit is a capital loan used for the purpose of increasing production in operations (Kasmir, 2010). The Capital Banking Credit sourced from Statistics Indonesia (BPS).

2. The exchange rate is the price level agreed upon by residents of the two countries to trade with each other (Mankiew, 2006). The Exchange Rate sourced from The International Monetary Fund (IMF).

3. Money Supply is the quantity of money available in the economy (Mankiew, 2006). The Money Supply sourced from The International Monetary Fund (IMF).

4. The Inflation rate is the annualized percentage change in a general price index over time (Mankiew, 2006). The Inflation Rate sourced from The International Monetary Fund (IMF). 
These data obtained from sources ranging from the period of $2010-2015$. The author uses the Eviews 9 software to process data and statistical tests to analyze the data.

\section{RESULT AND DISCUSSION}

Before regressing using the ECM test, a root test of the Augmented Dickey-Fuller (ADF) unit was carried out to determine whether the data is stationary or not.

Table 1. Summary of Stationary test

\begin{tabular}{|c|c|c|c|c|}
\hline \multirow{2}{*}{ Variables } & \multicolumn{2}{|c|}{ Level (I=0) } & \multicolumn{2}{c|}{ First Difference (I=0) } \\
\cline { 2 - 5 } & Statistics & Prob. & Statistics & Prob. \\
\hline $\begin{array}{c}\text { Banking } \\
\text { Credit(BC) }\end{array}$ & -0.906750 & 0.7799 & -9.933358 & 0.0000 \\
\hline $\begin{array}{c}\text { Exchange Rate } \\
\text { (ER) }\end{array}$ & 0.795917 & 0.9932 & -7.333879 & 0.0000 \\
\hline
\end{tabular}

Table 1. Summary of Stationary test (-continued)

\begin{tabular}{|c|c|c|c|c|}
\hline $\begin{array}{c}\text { Money Supply } \\
\text { (M2) }\end{array}$ & 0.594498 & 0.9885 & -7.450797 & 0.0000 \\
\hline Inflation (Inf) & -1.838174 & 0.3591 & -7.758206 & 0.0000 \\
\hline
\end{tabular}

As seen in Table 1, all variables are not stationary at the level. This condition will violate the Error Correction Model analysis rules if continued as the analysis using non-stationary variables will result in spurious regression. Therefore, it is necessary to proceed with the first-degree integration test. Based on the results of the first level integration test seen from the ADF test, all variables are stationary because the probability value is smaller than the significant level of 0.05 so it can be said that the data is stationary at the first degree.

Table 2. Cointegration Test

\begin{tabular}{lccc}
\hline \hline & & t-Statistic & Prob. $^{*}$ \\
\hline \hline \multicolumn{2}{l}{ Augmented Dickey-Fuller test statistic } & -4.468098 & 0.0006 \\
\hline Test critical values: & 1\% level & -3.538362 & \\
& 5\% level & -2.908420 & \\
& 10\% level & -2.591799 & \\
\hline \hline
\end{tabular}

*MacKinnon (1996) one-sided p-values. 
After knowing that all variables used in the study meet the stationary test requirements for the use of the ECM model, it should be assumed that these variables have cointegration. Cointegration can mean that there is a long-term relationship or balance between variables (Rosadi, 2016). The test statistic results in Table 2 show that the p-value of 0.0006 is smaller than the significance level $\alpha=0.05$. This conclusion means that this model has cointegration or has a long term relationship.

\section{Table 3. Long Term Estimation Result}

\begin{tabular}{|l|c||c||c|c|}
\hline $\begin{array}{l}\text { Dependent } \\
\text { Variable: } \\
\text { Banking Credit }\end{array}$ & Coefficient & Std. Error & t-stat & Prob. \\
\hline \hline$\alpha_{0}$ & -373196.0 & 325154.0 & -1.147751 & 0.2556 \\
\hline Exchange Rate & -48.41634 & 9.602454 & -5.042079 & 0.0000 \\
\hline Money Supply & 1.981035 & 0.062693 & 31.59892 & 0.0000 \\
\hline Inflation & 196976.8 & 59911.08 & 3.287820 & 0.0017 \\
\hline$R^{2}$ & 0.9911 & F-stat & \multicolumn{2}{|c|}{2248.229} \\
\hline \multirow{2}{*}{ Adj. $R^{2}$} & 0.9907 & Prob. F-stat & \multicolumn{2}{|c|}{0.00000} \\
\cline { 3 - 5 } & & Dw-stat & \multicolumn{2}{|c|}{} \\
\hline
\end{tabular}

As shown in Table 3, the result of the F test calculation is 2248.229 with a p-value of 0.0000 . The p-value that is less than 5 percent significance, leads to the decision to reject Ho. Thus, it can be concluded that there is at least one independent variable that affects Capital Banking Credit.

The long term equation is as follows:

$$
B C_{t}=-373196-48.4163 \mathrm{Er}_{t}{ }^{*}+1.981 M 2_{t}{ }^{*}+196976.8 \text { Inflasi }_{t}{ }^{*}
$$

The model has a coefficient of determination (Adjusted $R^{2}$ ) of 0.9907 , which indicates that $99.07 \%$ of the dependent variable's variation can be explained by the independent variables in the model. The long term model partially shows that the greater the values of Money Supply and Inflation will significantly affect Capital Banking Credit in a positive direction, while the greater the exchange rate value will significantly affect Capital Banking Credit in a negative direction.

The regression coefficient value of the money supply amounted to 1.981 means that the increase in the money supply amounted to Rp. 1 billion will be able to increase the total Capital Banking Credit by 1.981 billion rupiahs. Meanwhile, inflation has a positive and significant effect on capital credit. The inflation regression coefficient value of 196976.8 means that an increase of one unit in the inflation rate will increase Capital Banking Credit by Rp. 196976.80 billion rupiahs. The effect of the exchange rate on Capital Banking Credit is negative and significant. The Exchange Rate regression coefficient value 
Jurnal Lebesgue : Jurnal Ilmiah Pendidikan Matematika, Matematika dan Statistika

M. Rismawan Ridha,

Volume 1, No. 2, Agustus 2020 hal.82-90

DOI Artikel : 10.46306/lb.v1i2.19

of -48.42 means that an increase in the Exchange rate will decrease Capital Banking Credit by Rp. 48.42 billion rupiahs.

This result is in line with the findings by Auel (2011). The macroeconomic variables in the long term, such as money supply, exchange rates, and inflation influence financial system stability, which in this case is measured by the performance of Capital Banking Credit. For instance, they showed that a greater rate of exchange flexibility reduces the ability to stabilize the financial system, which reduces the role of external factors affecting domestic credit dynamics (Awdeh, 2017). In reverse, the growth of the money supply give a positive impact and will boost the bank supply of loans. Also, higher inflation rates are associated with higher capital buffers of banks, which in this case, contributing to increases in the financial stability system.

Table 4. Short Term (ECM) Estimation Result

\begin{tabular}{|c|c|c|c|c|}
\hline $\begin{array}{l}\text { Dependent } \\
\text { Variable: } \\
\text { D(Banking Credit) }\end{array}$ & Coefficient & Std. Error & t-stat & Prob. \\
\hline$\beta_{0}$ & 15622.96 & 3321.637 & 4.703392 & 0.0000 \\
\hline D(Exchange Rate) & 14.15080 & 11.73420 & 1.205945 & 0.2327 \\
\hline D(Money Supply) & 0.127392 & 0.241928 & 0.526567 & 0.6005 \\
\hline
\end{tabular}

Table 4. Short Term (ECM) Estimation Result (-continued)

\begin{tabular}{|l|c|l|r|c|}
\hline D(Inflation) & 183593.2 & 68317.58 & 2.687349 & 0.0094 \\
\hline ECT & -0.221666 & 0.081944 & -2.705101 & 0.0089 \\
\hline$R^{2}$ & 0.2647 & F-stat & \multicolumn{2}{|c|}{5.2211} \\
\hline \multirow{2}{*}{ Adj. $R^{2}$} & \multirow{2}{*}{0.2140} & Prob. F-stat & \multicolumn{2}{|c|}{0.0011} \\
\cline { 3 - 5 } & & Dw-stat & \multicolumn{2}{|c|}{2.3261} \\
\hline
\end{tabular}

The short term equation (Error Correction Model) is as follows:

$$
D\left(B C_{t}\right)=15622.96^{*}+14.1508 D\left(E r_{t}\right)+0.1274 D\left(M 2_{t}\right)+183593.2 D\left(\text { Inflasi }_{t}^{*}\right)-0.2216 \hat{\varepsilon}_{t-1}{ }^{*}
$$

In the short term, the effect of the exchange rate on the Capital Banking Credit is positive but not significant. This result is the same as the money supply that also not significantly affects Capital Banking Credit. On the other hand, inflation in the short term has a positive and significant effect on the Capital Banking Credit. The inflation regression coefficient value of 183593.2 means that an increase of one unit in the inflation rate will increase the Capital Banking Credit by Rp. 183593.2 billion rupiahs. Overall, these results are in line with the findings by Korkmaz (2015). 
The short term regression results show that the speed of adjustment is significant and has a negative value which is in the range -1 to 0 . This result means that the ECM equation is well-formed and the model is worth and valid as an analysis tool. The speed of adjustment value of 0.2216 means that the dependent and independent variables in this study are mutually integrated with the short term disturbances will be corrected every month by 22.16 percent. This ECM model also meets all the classical assumptions so that the estimator is "Best Linear Unbiased Estimator" (BLUE).

\section{CONCLUSION}

In the long term, the exchange rate, money supply, and inflation significantly influence the stability of the financial system measured through the capital banking credit position. But in the short term, only inflation has a significant effect on capital banking credit position in Indonesia. The speed of adjustment in the short term regression is significant and has a negative value. This state that the ECM equation is well-formed and the model is suitable for the analysis.

Based on the conclusions above, some suggestions given are as follows; a special effort is needed by the government to control the inflation rate so that it is at a good threshold to maintain the stability of the financial system in Indonesia. Besides, to still utilizing the error term as a correction mechanism and providing a comparison results, it is necessary to further explore the possibility of another modeling for this problem such as modeling with the Vector Autoregression (VAR) as well as Vector Error Correction Model (VECM) method.

\section{REFERENCE}

Ali, Awdeh. 2017. The Determinant of Credit Growth in Lebanon. International Business Research. Vol. 10, No. 2

Auel, M.\& Helder, F, M. 2011. Macroeconomic relevance of credit channels: Evidence from an emerging economy under inflation targeting. Journal of Economic Modelling. 28 (3): 965-979

Korkmaz, S. 2015. Impact of Bank Credits on Economic Growth and Inflation. Journal of Applied Finance and Banking. Vol. 5, No. 1. Sciencepress Ltd.

Kasmir. 2010. Manajemen Perbankan. Depok: RajaGrafindo Persada Press.

Mankiew, N. G. 2006. Macroeconomics. New York: Worth Publisher Press.

Mariusz, P. \& Katarzyna, W. 2016. The impact of the financial system on economic growth in the context of the global crisis: empirical evidence for the EU and OECD countries. Empirica. Vol. 44, 10.1007/s10663-016-9323-9

Matthew, L. \& Kraft, P. 2017. The General Error Correction Model in Practice. Research and Politics. 4. $205316801771305.10 .1177 / 2053168017713059$. 
Mekki, H \& Maktouf, S. 2018. Overall effects of financial liberalization: financial crisis versus economic growth. Journal Of International Review of Applied Economics. 1-28. 10.1080/02692171.2018.1515898.

Negara, H. R. P., Tamur, M., Syaharuddin, Apandi, T. H., Kusuma, J. W., \& Hamidah. (2020). Computational modeling of ARIMA-based G-MFS methods: Long-term forecasting of increasing population. International Journal of Emerging Trends in Engineering Research, 8(7), 3665-3669. https://doi.org/10.30534/ijeter/2020/126872020

Patcharee, P., et al. 2018. Economic integration in the Asean and its effect on empirical economic growth. Journal Of Applied Economic Sciences. Vol. 13, 922-935.

Robert, Kissel. \& Poserina, James. 2017. Optimal Sports Math, Statistics, and Fantasy. Newyork: Academic Press.

Rosadi, Dedi. 2016. Analisis Runtun Waktu dan Aplikasinya dengan R. Yogyakarta:. Gadjah Mada University Press.

Ruiz E, M. 2019. An Introduction to The Hybrid Economics Models. 10.13140/RG.2.2.23045.29920/1.

Smith, Jeremy and Otero, J. (2000) Testing for cointegration : power versus frequency of observation further Monte Carlo results. Economics Letters, Volume 67 (Number 1). pp. 5-9. Warwick University doi:10.1016/S0165-1765(99)00245-1

Tursoy, T. 2017. Causality between Stock Prices and Exchange Rates in Turkey: Empirical Evidence from the ARDL Bound Test and a Combined Cointegration Approach. Journal Of Financial Studies. 5,8. 10.3390/ijfs5010008 